\title{
New Phenylaminopyrimidine (PAP) Anticancer Lead Compound with High Efficacy: Design, Synthesis, and in vitro Screening
}

\author{
Ibrahim Mustafa El-Deeb, ${ }^{\dagger,}$, Dong Keun Han, ${ }^{\dagger}$ In Tae Kim, ${ }^{\S}$ and So Ha Lee ${ }^{\dagger, *}$ \\ ${ }^{\dagger}$ Life/Health Division, Korea Institute of Science and Technology, P.O. Box 131, Cheongryang, Seoul 130-650, Korea \\ ${ }^{*}$ E-mail:LSH6211@kist.re.kr \\ ${ }^{\sharp}$ Department of Biomolecular Science, University of Science and Technology, Daejeon 305-333, Korea \\ ${ }^{\S}$ Department of Chemistry, Kwangwoon University, Seoul 139-701, Korea \\ Received March 15, 2010, Accepted May 3, 2010
}

\begin{abstract}
Phenylaminopyrimidines represent a large group of new selective anticancer agents, the majority of which exert their action through the inhibition of specific kinases. In this study, a new series of $N$-substituted-2-aminopyrimidines has been designed and synthesized. A selected group of the synthesized derivatives was screened at a single dose concentration of $10 \mu \mathrm{M}$ over a panel of 60 cancer cell-lines. Compound 12e has showed great inhibitory and strong lethal effect over almost all of the 60 cell-lines and accordingly was further tested in a 5-dose testing mode to determine its $\mathrm{IC}_{50}$ values, where it showed great efficacies with intermediate potencies over the tested cell-lines. The compound was also tested over a panel of 52 kinases to explore its kinase inhibitory profile, and was found to be a selective but moderate inhibitor over FLT3 kinase.
\end{abstract}

Key Words: Phenylaminopyrimidines, Kinase inhibitor, Cancer cell-lines, Selectivity, Cancer

\section{Introduction}

Cancer remains to be one of the major causes of mortalities in the world, and researches directed towards the understanding of cancer molecular mechanisms as well as the development of new cancer therapies still occupy a high research priority. In order to overcome the poor selectivity of classical anticancer drugs and improve their limited efficiencies, a big deal of research in the field of drug design of new anticancer agents has been made in the last few decades. The development of new small molecular drugs that are capable of targeting the substantial cause of cancer and inhibiting "selectively" cancer growth was successfully achieved in the last few years. Contrasting for classical anticancer drugs, the majority of these new small molecules do not interact directly with DNA, while interrupt an essential cellular signaling pathway that is "abnormally" up-regulated in cancerous cells and at the same time is essential for its survival. ${ }^{1}$ These small molecular agents belong to different chemical scaffolds, and could be divided into variable groups according to their inhibitory mechanisms.

Phenylaminopyrimidines (PAPs) represent a large chemical group of these new anticancer agents, the majority of which exert their anticancer action through the inhibition of certain protein kinases. A representative example and a lead compound for such group is the Bcr-Abl tyrosine kinase inhibitor, Imatinib (Gleevec, STI-571). ${ }^{2}$ Imatinib, a PAP derivative, was the first kinase inhibitor to be approved for the treatment of cancer. After the successful approval of Imatinib as a selective anticancer drug for treatment of chronic myeloid leukemia (CML) with minimal side effects, relative to old anticancer drugs, numerous kinase inhibitors targeting oncogenic kinases have been developed. A large number of these kinase inhibitors belong to the same chemical group of Imatinib, PAPs. These compounds include inhibitors for kinases such as Bcr-Abl, ${ }^{3,4} \mathrm{CDK},{ }^{7} \mathrm{c}-\mathrm{KIT},{ }^{5}$

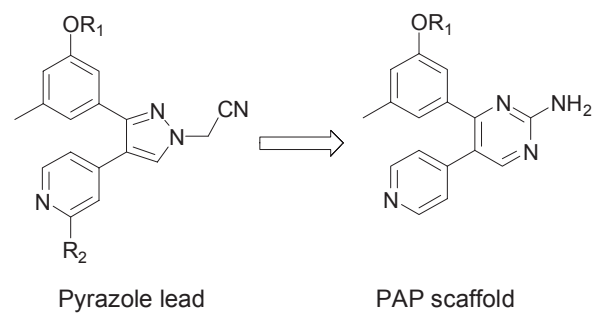

Figure 1. Rational design of the new PAP scaffold.

EGFR, ${ }^{4,6} \mathrm{Lyn}^{4}$ and PLK $1^{7}$ kinases. In addition to kinase inhibition, some anticancer PAPs modulate certain receptors such as the angiopoietin Tie 2 receptors. ${ }^{8}$

Accordingly, we have designed a new series of $N$-substituted2-aminopyrimidine derivatives based on the scaffold of the pyrazole kinase inhibitors previously prepared by our group, 9,10 where the pyrazole moiety was replaced by the 2-aminopyrimidine scaffold as showed in Figure 1, following this by a series of substitutions at the amino group to yield the target PAP derivatives.

A selected group from the target compounds were then tested over a panel of 60 cancer cell lines at a single dose of $10 \mu \mathrm{M}$, and the most active compound 12e, was further tested in a five-dose testing mode to determine its $\mathrm{IC}_{50}$ values over the 60 cell lines. The compound was also tested over a panel of 52 kinases, in order to determine its kinase inhibitory profile.

\section{Results and Discussion}

The synthesis of the target compounds started with the preparation of the key ester, methyl 3-methoxy-5-methylbenzoate (4) as illustrated in Scheme 1. In the first step, the sodium salt of ethyl 2-hydroxy-4-oxopent-2-enoate (1) was prepared accord- 

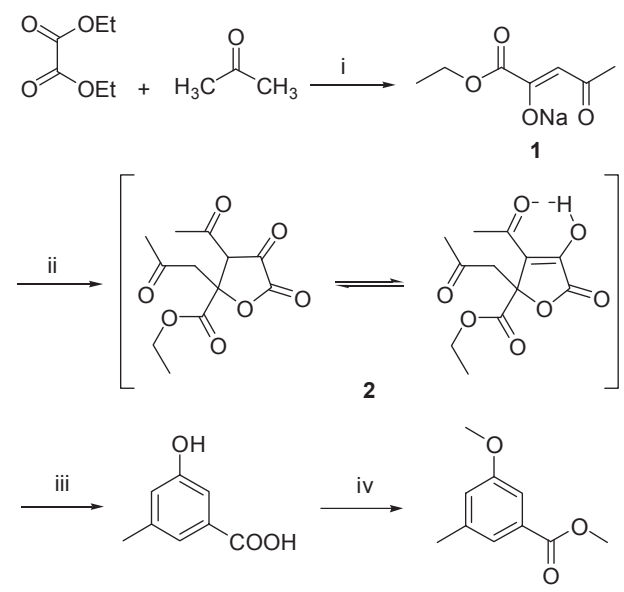

Reaction conditions and yields: (i) NaOEt, abs. EtOH, rt, 4h, 87\%; (ii) acetic acid : $\mathrm{H}_{2} \mathrm{O}$ (1:1), rt, 2h, 50\%; (iii) $\mathrm{MgO}, \mathrm{H}_{2} \mathrm{O}$, reflux, $45 \mathrm{~min}, 42 \%$; (iv) $\mathrm{K}_{2} \mathrm{CO}_{3}, \mathrm{CH}_{3}$ l, DMAP, acetone, $65{ }^{\circ} \mathrm{C}, 12 \mathrm{~h}, 93.5 \%$
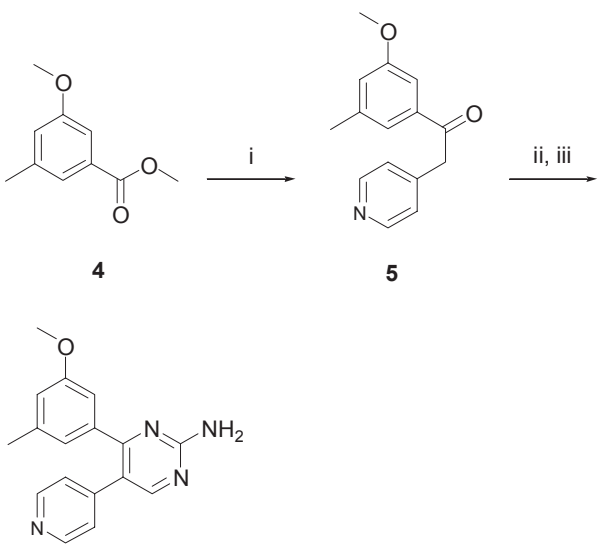

Reaction conditions and yields: (i) 4-methylpyridine, LHMDS, THF, $\mathrm{N}_{2}$ rt, 18 h, 99\%; (ii) DMF-DMA, reflux, 12 h; (iii) NaOEt, guanidine- $\mathrm{HCl}$, abs. $\mathrm{EtOH}$, reflux, $8 \mathrm{~h}, 62 \%$

\section{Scheme 1}

Scheme 2

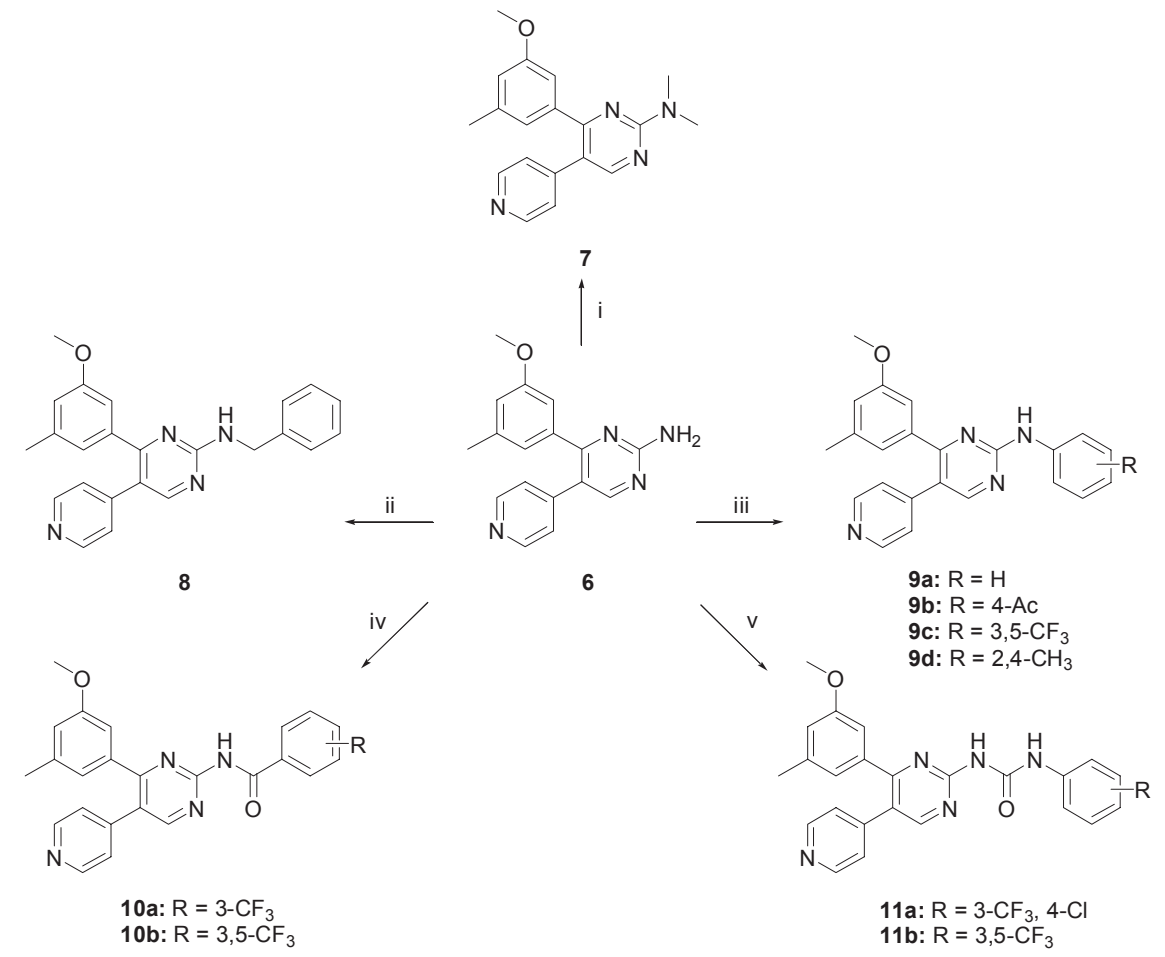

Reaction conditions and yields: (i) $\mathrm{CH}_{3} \mathrm{l}, \mathrm{NaH}, \mathrm{DMF}, \mathrm{N}_{2}, \mathrm{rt}, 24 \mathrm{~h}, 19 \%$; (ii) benzylchloride, $\mathrm{K}_{2} \mathrm{CO}_{3}, \mathrm{DMF}, 80{ }^{\circ} \mathrm{C}, 4 \mathrm{~h}, 34 \%$; (iii) arylbromide, $\mathrm{Pd}\left(\mathrm{PPh}_{3}\right)_{2} \mathrm{Cl}_{2}$, Xantphos, NaOtBu, toluene, reflux, 12h, 79\%; (9a), 76\% (9b), 74\% (9c), 66\% (9d); (iv) ArCOCl, pyridine, reflux, 4 h, 59\% (10a), 63\% (10b); (v) ArNCO, fusion, $120{ }^{\circ} \mathrm{C}, 1 \mathrm{~h}, 70 \%$ (11a), $72 \%$ (11b)

Scheme 3

ing to literature procedure, ${ }^{11}$ through the condensation of diethyl oxalate with acetone in the presence of sodium ethoxide in absolute ethanol.

The resulted salt 1 was then cyclized into Claisen furan derivative 2 by heating in $50 \%$ acetic acid followed by acidification with sulfuric acid. ${ }^{12}$ The resulted Claisen compound underwent rearrangement and aromatization into 3-hydroxy-5-methylbenzoic acid (3) within less than one hour by heating with magnesium oxide in boiling water, followed by acidification with hy- drochloric acid to precipitate the product. ${ }^{12}$ Methyl esterification and $O$-methylation of the resulted phenolic acid $\mathbf{3}$ were achieved in a single step and in a high yield (94\%) to give compound 4 through a little modification of the reported literature procedure, ${ }^{13}$ where the acid $\mathbf{3}$ was refluxed with excess potassium carbonate and iodomethane in acetone, and in the presence of a catalytic amount of dimethylaminopyridine.

In Scheme 2, the benzoate ester 4 underwent a nucleophilic attack at its carboxylic carbon by the activated methylene group 

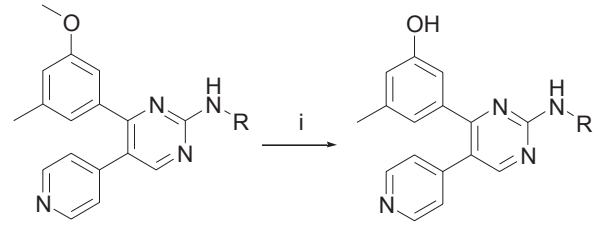

6: $\mathrm{R}=\mathrm{H}$

8: $R$ = benzyl

9a: $R=$ pheny

9b: $R=4-$ Ac-phenyl

9c: $\mathrm{R}=3,5-\mathrm{CF}_{3}$-pheny

9d: $\mathrm{R}=2,4-\mathrm{CH}_{3}$-phenyl

10a: $\mathrm{R}=3-\mathrm{CF}_{3}$-benzoyl

12a: $\mathrm{R}=\mathrm{H}$

12b: $R=$ benzyl

12c: $R=$ phenyl

12d: $R=4-A c-$ pheny

12e: $\mathrm{R}=3,5-\mathrm{CF}_{3}$-phenyl

12f: $\mathrm{R}=2,4-\mathrm{CH}_{3}$-phenyl

12g: $\mathrm{R}=3-\mathrm{CF}_{3}$-benzoyl

Reaction conditions and yields: (i) $\mathrm{BF}_{3} \cdot \mathrm{S}\left(\mathrm{CH}_{3}\right)_{2}$, dichloromethane, $\mathrm{N}_{2}$, rt, 24 h, 55\% (12a), 47\% (12b), 42\% (12c), 51\% (12d), 40\% (12e), 46\% (12f), 63\% (12g)

Scheme 4

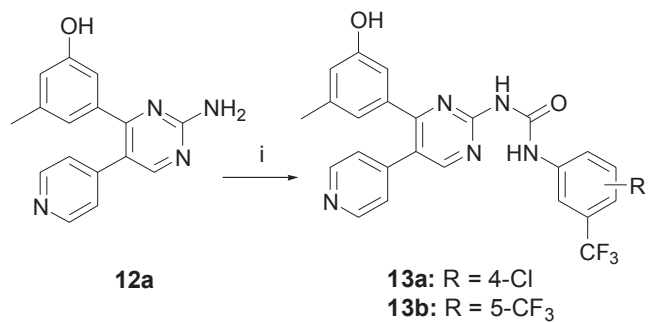

Reaction conditions and yields: (i) ArNCO, fusion, $120^{\circ} \mathrm{C}, 1 \mathrm{~h}, 64 \%$ (13a), $77 \%$ (13b)

Scheme 5

of 4-methylpyridine (4-picoline). The activation of this methyl group into an active methylene was achieved by dropwise addition of lithium bis(trimethylsilyl)amide (LHMDS) in dry THF at room temperature. The resulted $\alpha, \beta$-unsaturated ketone $\mathbf{5}$ was then converted to the required pyrimidin-2-amine derivative $\mathbf{6}$ through two successive steps. In the first step, compound $\mathbf{5}$ was heated with excess $N, N$-dimethylformamide dimethylacetal for 12 hours, and the resulted product was taken to the next step without further purification, where it was cyclized with guanidine-hydrochloride in absolute ethanol and in the presence of sodium ethoxide into the pyrimidine derivative $\mathbf{6}$.

The key amine $\mathbf{6}$ was subjected to a group of different reactions to yield the methoxy-series of the target products (7-11) as showed in Scheme 3. N-Methylation with iodomethane in DMF and in the presence of sodium hydride yielded the $N, N$ dimethyl derivative 7 in 19\% yield.

Compound 8 was obtained by heating the amine 6 with benzylchloride in DMF and in the presence of $\mathrm{K}_{2} \mathrm{CO}_{3}$. Four different PAP derivatives 9a-d were prepared in good yields by direct $\mathrm{N}$-arylation of the amine $\mathbf{6}$ using the appropriate arylbromide, and applying an optimized Buchwald-Hartwig amination protocol previously adapted by our group. ${ }^{14} \mathrm{~N}$-Benzoylation of compound 6 was successfully achieved by refluxing it with 3-trifluoromethylbenzoyl chloride and 3,5-bis(trifluoromethyl)benzoyl chloride in pyridine to yield the benzoyl derivatives 10a and $\mathbf{1 0 b}$ in good yields, respectively. The urea derivatives 11a and
$11 \mathrm{~b}$ were obtained in satisfactory yields by fusion of the amine 6 with the appropriate phenylisocyanate derivative without solvent. Our trials to prepare these urea derivatives by reacting 6 with the isocyanates in different solvents, such as THF, toluene and pyridine, either fail completely to proceed the reaction or produce the intended urea in very small unsatisfactory yield.

The target of Scheme 4 was to prepare the hydroxy analogues of compounds 12a-12g under the effect of $\mathrm{BF}_{3}$-dimethylsulfide complex, in dichloromethane at room temperature. Under these conditions, all of the methoxy derivatives were successfully converted into their hydroxy-analogues, except for the urea compounds $11 \mathrm{a}$ and $\mathbf{1 1 b}$, since a destructive effect of $\mathrm{BF}_{3}$ on the N$\mathrm{C}-\mathrm{N}$ urea linkage was observed, prohibiting the direct preparation of the hydroxy derivatives 13a and 13b from their methoxy analogues following Scheme 4 protocol.

Accordingly, as showed in Scheme 5, compounds 13a and 13b were successfully prepared by fusing the hydroxy analog of the amine $\mathbf{6}$ (compound 12a) with the appropriate phenyl isocyanates in an analogous synthetic step to that used for the preparation of the urea compounds 11a and 11b in Scheme 3.

\section{Biological Screening}

In vitro anticancer screening. The structures of the final products were submitted to National Cancer Institute (NCI), Bethesda, Maryland, $\mathrm{USA}^{15}$ and the 12 compounds showed in Table 1 were selected on the basis of degree of structural variation and computer modeling techniques for evaluation of their antineoplastic activity. The selected compounds were subjected to in vitro anticancer assay against tumor cells in a full panel of 60cell lines taken from 9 different tissues (blood, lung, colon, CNS, skin, ovary, kidney, prostate and breast). The compounds were tested at a single dose concentration of $10 \mu \mathrm{M}$, and the percentages of growth inhibition over the sixty tested cell lines were determined. The mean inhibition percentages of all of the tested compounds over the full panel of cell-lines are illustrated in Table 1. As showed in Table 1, the tested compounds have expressed weak to moderate mean inhibition over the whole celllines panel except for compound 12e, where a great mean inhibition of $121.2 \%$ was observed over the cancer cell-lines, indicating that the compound effect has exceeded the inhibitory limit (100\% inhibition) to the lethal effect (regression of tumor size from the original size at the beginning of the experiment) at the test dose $(10 \mu \mathrm{M})$. The multiple inhibitions of compound 12e over the 60 cell-lines are illustrated in Figure 2. The inhibitory effect of the compound approaches the limit of $200 \%$ (100\% lethality or complete tumor regression) in some of the cell lines under test at the test dose. The inhibitory effect is very strong over almost all of the 60 cell-lines, with a significant lethality at some of colon and melanoma cell-lines.

By referring to the inhibitory effects of the tested compounds summarized in Table 1, it is clear that the substitution at the amino group of the new 4-phenyl-5-(pyridin-4-yl)pyrimidin-2amine scaffold has a positive effect on activity. However, the variation of the type of the added substituent is so critical for optimizing this positive effect. By comparing the activities of compounds $\mathbf{1 2 e}$ and $\mathbf{1 0 b}$, a great difference in activity was observed, although both of them bears a 3,5-bis(trifluoromethyl) 
Table 1. Compounds selected for single dose cancer cell-line screening and their mean inhibitory percentages

Inhibition $\%^{a}$

$\overline{a_{0}}$ Inhibition represents the mean inhibition percentages over the 60 cell lines. The inhibition percentages are calculated by subtracting the growth percentages from 100.

phenyl moiety linked to the 2-aminopyrimidine group. However, in compound $\mathbf{1 0 b}$, the 3,5-bis(trifluoromethyl)phenyl moiety is linked through a carbonyl group forming an amide, while the moiety is directly attached to the amino group in $\mathbf{1 2 e}$.

The observed big difference in activity associated with this slight change in structure reflects the strictness of structural changes at this part of the molecule. The difference in activity between these two molecules cannot be explained on the basis of excessive bulkiness exerted by the insertion of carbonyl group between the amino- and the 3,5-bis(trifluoromethyl)phenyl moieties, since in this sense, a much lower activity would be expected for compound $\mathbf{1 3 b}$ having the 3,5-bis(trifluoromethyl)phenyl moiety spaced from the amino group by an additional -NH- to form this time a urea linkage between the pyrimidine ring and the 3,5-bis(trifluoromethyl)phenyl moiety. This was proved, however, to be incorrect, since the activity of compound $\mathbf{1 3 b}$ is much higher than that of $\mathbf{1 0 b}$.

On these bases, we can conclude that in this new class of 2aminopyrimidines, substitution with benzoyl moieties has the worst effect on activity, while urea derivatives are relatively better, however, the best activity would be obtained by direct attachment of a suitably substituted phenyl ring to the amino group of the pyrimidin-2-amine scaffold. Within the $\mathrm{N}$-phenyl series, a substituted phenyl is likely more efficient than unsubstituted one (9a \& 12c), and the 3,5-disubstitution pattern (in 12e) seems to be the optimum for activity, relative to 4-monosubstitution (in 12d), and 2,4-disustitution (in 9d). By comparing the activities of different methoxy compounds with the activities of their hydroxy analogues, it was difficult to correlate between the demethylation effect and the change in activity. The effect of demethylation was found to be inconsistent with the change in activity, where the demethylation of compounds $9 \mathbf{a}$ and 10a to 


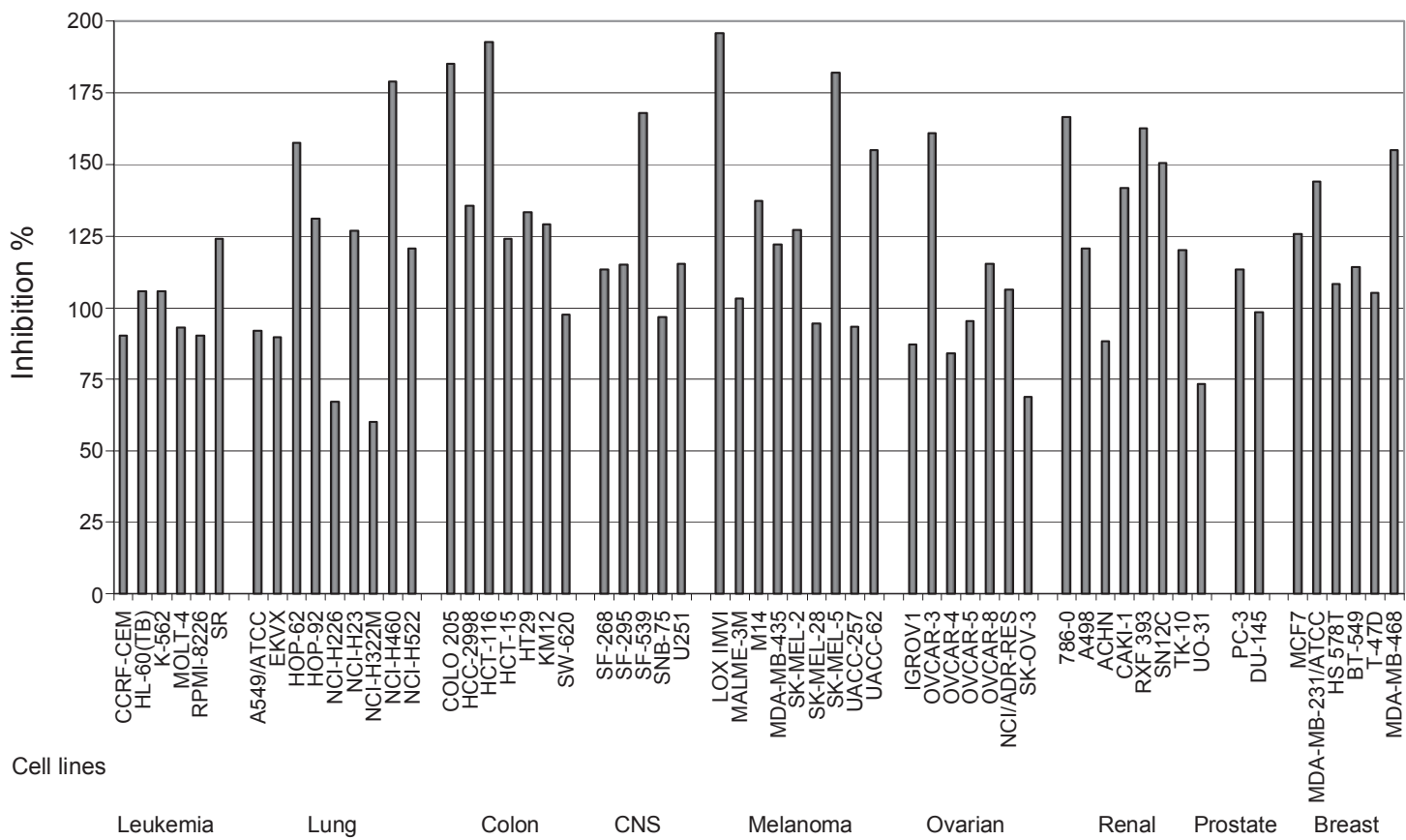

Figure 2. Inhibition percentages of compound 12e at a single dose concentration of $10 \mu \mathrm{M}$ over 60 cancer cell-lines.

Table 2. $\mathrm{IC}_{50}$, TGI and $\mathrm{LC}_{50}$ values in $\mu \mathrm{M}$ of compound $12 \mathrm{e}$ over 60 cancer cell-lines.

\begin{tabular}{|c|c|c|c|c|c|c|c|c|c|}
\hline & Cell line & $\mathrm{IC}_{50}{ }^{a}$ & $\mathrm{TGI}^{b}$ & $\mathrm{LC}_{50}{ }^{c}$ & & Cell line & $\mathrm{IC}_{50}{ }^{a}$ & $\mathrm{TGI}^{b}$ & $\mathrm{LC}_{50}{ }^{c}$ \\
\hline \multirow{7}{*}{ Leukemia } & CCRF-CEM & 1.99 & 7.17 & $>100$ & \multirow{8}{*}{ Melanoma } & LOX IMVI & 1.58 & 2.95 & 5.37 \\
\hline & HL-60(TB) & 1.78 & 5.75 & $>100$ & & MALME-3M & 1.45 & 3.16 & 6.92 \\
\hline & K-562 & 0.65 & 3.09 & $>100$ & & MDA-MB-435 & 0.47 & 1.78 & 4.68 \\
\hline & MOLT-4 & 1.74 & 5.25 & $>100$ & & SK-MEL-2 & 1.45 & 2.88 & 5.89 \\
\hline & RPMI-8226 & 2.34 & 7.41 & $>100$ & & SK-MEL-28 & 1.58 & 3.02 & 5.62 \\
\hline & & & & 100 & & SK-MEL-5 & 1.38 & 2.69 & 5.13 \\
\hline & SR & 0.34 & 1.78 & $>100$ & & UACC-257 & 1.82 & 4.27 & 10.72 \\
\hline \multirow{9}{*}{$\begin{array}{l}\text { Non-Small Cell } \\
\text { Lung Cancer }\end{array}$} & A549/ATCC & 1.7 & 3.16 & 6.03 & & UACC-62 & 2.34 & 4.17 & 7.24 \\
\hline & EKVX & 1.74 & 4.68 & 26.92 & \multirow{7}{*}{ Ovarian Cancer } & IGROV1 & 1.74 & 3.72 & 7.94 \\
\hline & HOP-62 & 1.55 & 2.88 & 5.37 & & OVCAR-3 & 1.58 & 2.95 & 5.62 \\
\hline & HOP-92 & 1.35 & 2.75 & 5.5 & & OVCAR-4 & 1.95 & 3.88 & 7.76 \\
\hline & NCI-H226 & 1.66 & 3.24 & 6.31 & & OVCAR-5 & 1.86 & 3.55 & 6.92 \\
\hline & NCI-H23 & 1.82 & 3.8 & 7.94 & & OVCAR-8 & 2.09 & 4.37 & 9.33 \\
\hline & NCI-H322M & 2.04 & 5.13 & 20.42 & & NCI/ADR-RES & 1.38 & 3.31 & 7.94 \\
\hline & NCI-H460 & 1.78 & 3.39 & 631 & & SK-OV-3 & 1.78 & 4.17 & $>100$ \\
\hline & NCI-H522 & 1.1 & 2.59 & 0.51 & \multirow{8}{*}{ Renal Cancer } & $786-0$ & 1.62 & 2.95 & 5.5 \\
\hline \multirow{8}{*}{ Colon Cancer } & COLO 205 & 1.78 & 3.23 & 4.19 & & A498 & 0.56 & 2.09 & 4.57 \\
\hline & HCC-2998 & & 3.10 & 5.02 & & ACHN & 2.57 & 7.59 & 33.88 \\
\hline & HCT-116 & 1.1 & 3.09 & 5.02 & & CAKI-1 & 1.48 & 3.89 & 9.99 \\
\hline & & 1.55 & 2.88 & 5.37 & & RXF 393 & 1.26 & 2.51 & 5.01 \\
\hline & НCТ-15 & 2.09 & 6.03 & $>100$ & & $\mathrm{SN} 12 \mathrm{C}$ & 1.91 & 3.47 & 6.46 \\
\hline & HT29 & 1.58 & 2.95 & 5.5 & & TK-10 & 1.91 & 3.31 & 5.89 \\
\hline & KM12 & 1.23 & 2.51 & 5.01 & & UO-31 & 1.41 & 2.75 & 5.37 \\
\hline & SW-620 & 1.58 & 3.16 & $>100$ & \multirow{2}{*}{ Prost. } & PC-3 & 1.29 & 2.63 & 5.37 \\
\hline \multirow{7}{*}{ CNS Cancer } & SF-268 & 1.48 & 3.02 & 6.17 & & DU-145 & 1.58 & 2.95 & 5.37 \\
\hline & SF-295 & 1.58 & 3.16 & 6.31 & \multirow{6}{*}{ Breast Cancer } & MCF7 & 1.62 & 3.17 & 6.03 \\
\hline & SF-539 & 178 & 3.47 & 676 & & MDA-MB-231/ATCC & 1.86 & 3.98 & $>100$ \\
\hline & SNB-19 & 14 & 38 & 0.10 & & HS 578T & 1.82 & 6.46 & $>100$ \\
\hline & 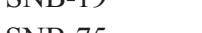 & 2.14 & 3.0 & 6.61 & & ВТ-549 & 1.78 & 3.47 & 6.61 \\
\hline & SNB-75 & 1.48 & 3.16 & 6.76 & & T-47D & 2.29 & 7.24 & 44.67 \\
\hline & U251 & 1.58 & 2.88 & 5.37 & & MDA-MB-468 & 1.55 & 3.16 & 6.46 \\
\hline
\end{tabular}

${ }^{a} \mathrm{IC}_{50}$ Is the concentration producing $50 \%$ inhibition, ${ }^{b} \mathrm{TGI}$ is the concentration producing $100 \%$ inhibition, ${ }^{c} \mathrm{LC}_{50}$ is the concentration causing $50 \%$ lethality (50\% tumor regression). 

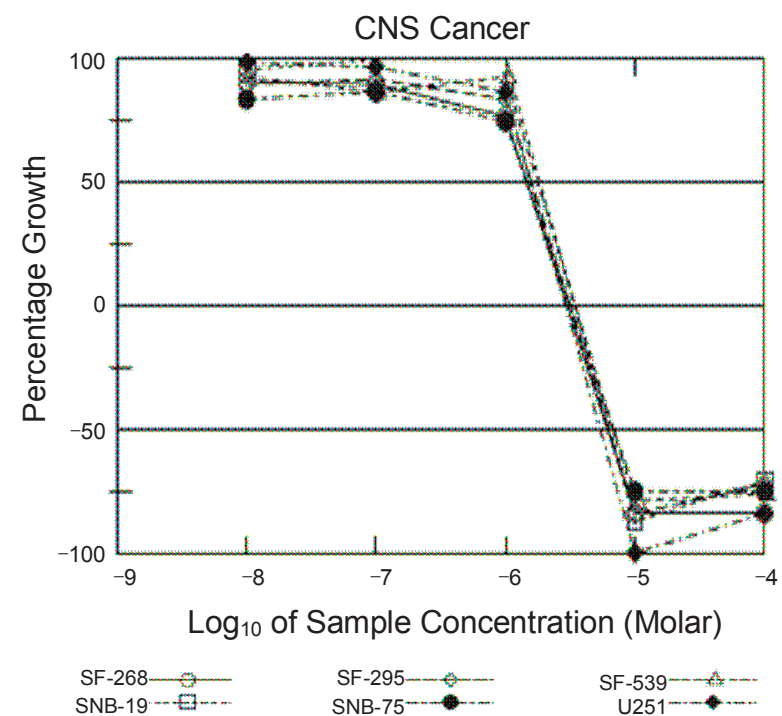

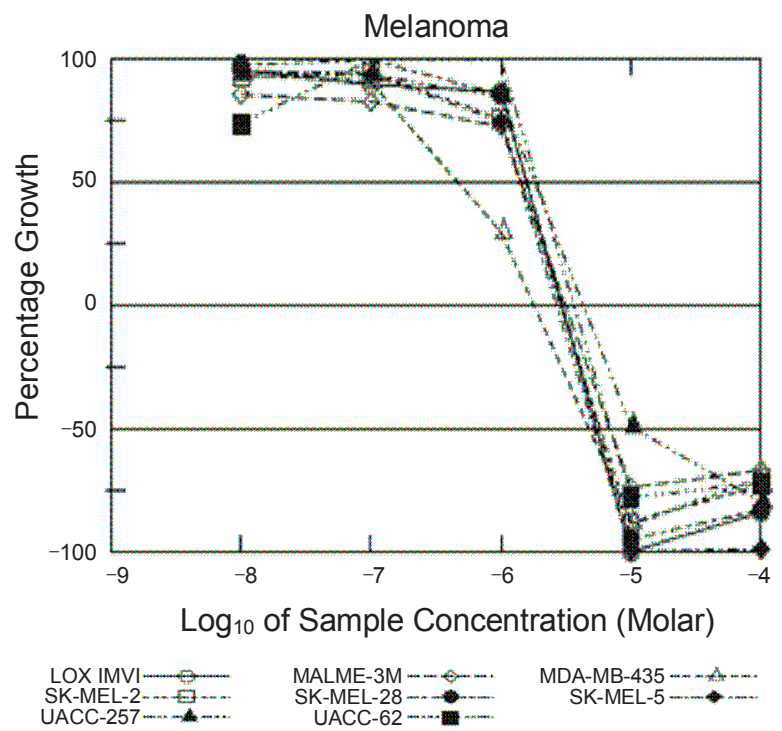

Figure 3. Dose-response curves for compound 12e over CNS tumors (upper panel) and melanoma (lower panel).

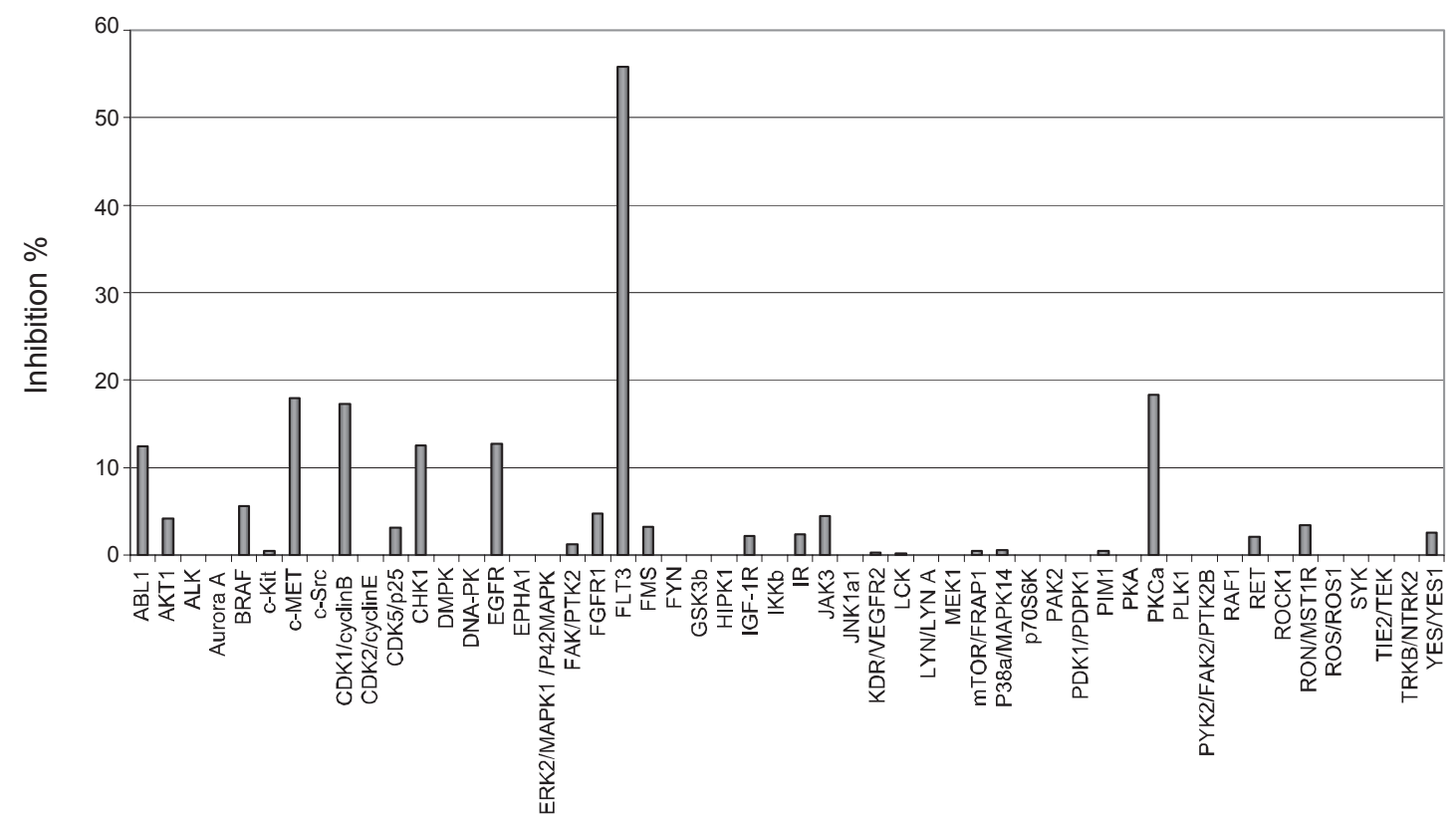

Kinase

Figure 4. Inhibition percentages of compound 12e at a single dose concentration of $10 \mu \mathrm{M}$ over 52 kinases.

the corresponding $12 \mathrm{c}$ and $12 \mathrm{~g}$ was found to decrease the activity, respectively, while the similar conversion of compound $\mathbf{9 b}$ to 12d was associated with increase in activity.

From these data we can conclude that a 3,5-bis(trifluoromethyl)phenyl moiety attached directly to the amino group of the pyrimidin-2-amine scaffold is optimum for activity. However, further exploration of the effect of structural variations at the 3hydroxy-5-methylphenyl and pyridin-4-yl moieties on activity would be important for further optimization of this new class of compounds.

After the initial single dose screening of the 12 selected compounds, compound 12e was further tested in a five-dose testing mode to determine its $\mathrm{IC}_{50}$ values over the 60 tumor cell-lines. The $\mathrm{IC}_{50}$ (the concentration producing 50\% inhibition), TGI (the concentration producing $100 \%$ inhibition) and $\mathrm{LC}_{50}$ (the concentration causing $50 \%$ lethality or $50 \%$ tumor regression) at all the tested cell lines were recorded. The compound has showed great efficacy over almost all of the tested cell lines but unfortunately with a moderate potency, having $\mathrm{IC}_{50}$ values ranging from $0.34 \mu \mathrm{M}$ in SR leukemia cells to $2.57 \mu \mathrm{M}$ in ACHN renal cells (Table 2). As a representative model for compound 12e inhibitory effect, the dose response curves of the compound over CNS and melanoma cancer cell-lines are showed in Figure 3, where a strong and sharp steeping inhibition of the compound 
within a small concentration range is observed.

The high efficacy of the compound was demonstrated by its ability to induce total growth inhibition (Zero growth, TGI) over all the tested cell lines in relatively small doses ranging between $1.78 \mu \mathrm{M}$ and $7.59 \mu \mathrm{M}$. The compound was also able to induce $50 \%$ tumor regression ( $50 \%$ lethality, $\mathrm{LC}_{50}$ ) in $81 \%$ of the tested cell lines ( 48 of 59), with $\mathrm{LC}_{50}$ values lower than 10 $\mu \mathrm{M}$ in $73 \%$ of the cell lines (43 of 59 ).

In vitro kinase screening. In order to explore the mechanism of anticancer effect of compound 12e, the compound was screened over a panel of 52 kinases at Reaction Biology Corporation, ${ }^{16}$ using Hot Spot Technique in a single dose duplicate mode at a concentration of $10 \mu \mathrm{M}$. At this concentration, the compound showed a moderate selective inhibition over FLT3 kinase. As showed in Figure 4, a 56\% inhibition of FLT3 activity was observed at the tested dose, suggesting an $\mathrm{IC}_{50}$ value below 10 $\mu \mathrm{M}$, while the inhibition was below $20 \%$ at all of the other 51 tested kinases.

FMS-related tyrosine kinase 3 (FLT3) is a member of the type III receptor tyrosine kinase family, which includes c-Kit, PDGFR and M-CSF receptors. FLT3 mutations have been reported in about $30 \%$ of cases of acute myeloid leukemia (AML), and the development of selective inhibitors that target this tyrosine kinase has been recently the focus of many research groups. ${ }^{17,18}$ A number of potent FLT3 inhibitors, such as Lestaurtinib (CEP701), ${ }^{19}$ ABT-869, ${ }^{20}$ MLN-518 ${ }^{21}$ and Fostamatinib, ${ }^{22}$ which differ in their selectivity profiles, both with respect to other kinases and among wild-type FLT3, are currently under preclinical and clinical investigations as potential drug candidates for AML.

The selective inhibition exerted by our new compound 12e is a good sign. However, it can not be considered as the reason behind the broad spectrum anticancer activity of the compound. The inhibition of the enzyme is not so high, and in spite of the moderate potency of the compound over cancer cell-lines, this kinase inhibitory profile cannot justify the broad activity and the high lethality of the compound over almost all cell-line types. The inhibition of FLT3 could be one of the mechanisms by which this compound exerts its anticancer effect, but we think that there is another more leading mechanism that is responsible for this strong antineoplastic effect.

\section{Conclusions}

In conclusion, a new PAP anticancer lead 12e with high efficacy over a wide range of cancer types has been emerged from this study. In spite of moderate potency of 12e, the compound has showed interesting high efficacy and lethality at almost all of the cell lines in the tested panel. The SAR made on the prepared series revealed that a 3,5-bis(trifluoromethyl)phenyl moiety that is directly attached to the amino group of the pyrimidine scaffold is optimum for activity. Further exploration of the effect of structural variations at the 3-hydroxy-5-methyl and pyridin-4-yl moieties would be helpful for better rationalization of this new series of anticancer agents and may lead to the production of more potent derivatives. The compound has been tested also over a large panel of kinases, and showed a selective but moderate inhibitory effect on FLT3 kinase which is not enough to account for its broad spectrum anticancer effect.
Accordingly, further screening of compound 12e over a larger group of potential molecular targets is currently under processing.

\section{Experimental Section}

Material. ${ }^{1} \mathrm{H}-\mathrm{NMR}(300 \mathrm{MHz})$ and ${ }^{13} \mathrm{C}-\mathrm{NMR}(75 \mathrm{MHz})$ were recorded on a Bruker Avance 300 spectrometer with TMS as an internal standard. The IR spectra were recorded on Perkin Elmer Spectrum GX spectrometer. Melting points were taken on a Thomas-Hoover capillary melting apparatus and were uncorrected. Column chromatography was performed on Merck silica gel 60 (230 - 400 mesh). TLC was carried out using glass sheets precoated with silica gel 60 F254 prepared by E. Merck. All the commercially available reagents were obtained from Aldrich and Tokyo Kasei Chemicals and generally used without further purification.

Sodium ethyl 2-hydroxy-4-oxopent-2-enoate (1): To an ethanolic solution of sodium ethoxide prepared by dissolving sodium metal $(15.0 \mathrm{~g}, 0.66 \mathrm{~mol})$ in absolute ethanol $(330 \mathrm{~mL})$ was slowly added a mixture of diethyloxalate $(81 \mathrm{~mL}, 0.66 \mathrm{~mol})$ and acetone $(45 \mathrm{~mL}, 0.66 \mathrm{~mol})$ over a period of $2-3 \mathrm{~h}$. After complete addition, the mixture was stirred at room temperature for 1 more hour. The resulted precipitate was collected by filtration, washed with ethanol, and dried to give the title compound $\mathbf{1}$ as a light yellow powder (103.5 g, 87\%): mp > $300{ }^{\circ} \mathrm{C} ;{ }^{1} \mathrm{H}-\mathrm{NMR}$ $\left(\mathrm{D}_{2} \mathrm{O}\right) \delta 1.14(\mathrm{t}, J=8.7 \mathrm{~Hz}, 3 \mathrm{H}), 1.83(\mathrm{~s}, 1 \mathrm{H}), 2.07(\mathrm{~s}, 2 \mathrm{H}), 4.08$ $(\mathrm{q}, J=9.6 \mathrm{~Hz}, 2 \mathrm{H}) ;{ }^{13} \mathrm{C}-\mathrm{NMR}\left(\mathrm{D}_{2} \mathrm{O}\right) \delta 13.05,13.18,27.65$, 28.17, 62.38, 168.88, 170.94, 200.65.

Ethyl 3-acetyl-tetrahydro-4,5-dioxo-2-(2-oxopropyl)furan2-carboxylate (2): A mixture of sodium ethylacetopyruvate (1; $96 \mathrm{~g}, 0.54 \mathrm{~mol})$, acetic acid $(150 \mathrm{~mL})$ and water $(150 \mathrm{~mL})$ was stirred at room temperature for $2 \mathrm{~h}$. The mixture was poured over a mixture of crushed ice ( $300 \mathrm{~g})$ and concentrated sulfuric acid $(60 \mathrm{~mL})$. The resulted solid was filtered, washed with cold water and dried. Recrystallization from water gave compound $\mathbf{2}$ as a white powder $(72.9 \mathrm{~g}, 50 \%): \mathrm{mp} 87-88^{\circ} \mathrm{C}$ (lit. $\left.89-91{ }^{\circ} \mathrm{C}\right) ;{ }^{1} \mathrm{H}-$ NMR (DMSO- $\left.d_{6}\right) \delta 1.10(\mathrm{t}, J=7.1 \mathrm{~Hz}, 3 \mathrm{H}), 2.06(\mathrm{~s}, 3 \mathrm{H}), 2.36$ (s, 3H), $3.18(\mathrm{~d}, J=18.1 \mathrm{~Hz}, 1 \mathrm{H}), 3.63(\mathrm{~d}, J=18.1 \mathrm{~Hz}, 1 \mathrm{H}), 4.08$ $(\mathrm{q}, J=5.3 \mathrm{~Hz}, 2 \mathrm{H}) ;{ }^{13} \mathrm{C}-\mathrm{NMR}$ (DMSO- $\left.d_{6}\right) \delta 14.13,30.30,31.10$, 62.50, 82.65, 123.12, 150.47, 167.54, 168.52, 192.64, 204.27.

3-Hydroxy-5-methylbenzoic acid (3): To previously warmed water $(450 \mathrm{~mL})$ was added compound $2(57 \mathrm{~g}, 0.21 \mathrm{~mol})$ and magnesium oxide $(38.1 \mathrm{~g}, 0.95 \mathrm{~mol})$ while heating and stirring were maintained. The mixture immediately became deep reddish orange in color, and turned to light brown in about 15 minutes. Stirring and heating were maintained for extra 30 minutes after complete addition of solids. Excess magnesium oxalate and magnesium oxide were removed by filtration, washed with warm water, and the combined filtrate and washing were concentrated under vacuum to $30 \mathrm{~mL}$. The concentrated solution was cooled in an ice bath and treated in a dropwise manner with a mixture of concentrated $\mathrm{HCl}$ and water $(1: 1,50 \mathrm{~mL})$ while stirring to precipitate the crude product. The resulted solids were collected by filtration, washed with cold water and dried. Recrystallization from water yielded the pure product 3 as a light brown powder (13.43 g, 42\%): mp 202 - $203{ }^{\circ} \mathrm{C}$ (lit. 207 - 208 $\left.{ }^{\circ} \mathrm{C}\right) ;{ }^{1} \mathrm{H}-\mathrm{NMR}\left(\mathrm{D}_{2} \mathrm{O}\right) \delta 2.19(\mathrm{~s}, 3 \mathrm{H}), 6.82(\mathrm{~s}, 1 \mathrm{H}), 7.07(\mathrm{~s}, 1 \mathrm{H})$, 
$7.20(\mathrm{~s}, 1 \mathrm{H}) ;{ }^{13} \mathrm{C}-\mathrm{NMR}\left(\mathrm{D}_{2} \mathrm{O}\right) \delta 20.20,113.00,121.03,122.25$, $130.65,140.55,155.34,170.26$.

Methyl 3-methoxy-5-methylbenzoate (4): To a solution of compound 3 ( $9 \mathrm{~g}, 59.16 \mathrm{mmol})$ in acetone $(180 \mathrm{~mL})$ was added $\mathrm{K}_{2} \mathrm{CO}_{3}(33 \mathrm{~g}, 237.0 \mathrm{mmol})$, iodomethane $(37.2 \mathrm{~mL}, 591.6 \mathrm{mmol})$ and a catalytic amount of DMAP. The mixture was heated at 65 ${ }^{\circ} \mathrm{C}$ for $12 \mathrm{~h}$. Acetone was evaporated under reduced pressure, and the concentrated residue was partitioned between water $(300 \mathrm{~mL})$ and dichloromethane $(450 \mathrm{~mL})$. The aqueous layer was further extracted with dichloromethane $(300 \mathrm{~mL})$, and the combined organic extracts were dried over anhydrous $\mathrm{MgSO}_{4}$ and evaporated under vacuum. The residue was purified by column chromatography ( silica gel, ethyl acetate-hexane 1:12 v/v) to give the pure product 4 as a colorless oil $(9.98 \mathrm{~g}, 93.5 \%): R_{f}=$ 0.39 (hexane/EtOAc, 12:1); ${ }^{1} \mathrm{H}-\mathrm{NMR}\left(\mathrm{CDCl}_{3}\right) \delta 2.26(\mathrm{~s}, 3 \mathrm{H})$, $3.72(\mathrm{~s}, 3 \mathrm{H}), 3.81(\mathrm{~s}, 3 \mathrm{H}), 6.81(\mathrm{~s}, 1 \mathrm{H}), 7.28(\mathrm{~s}, 1 \mathrm{H}), 7.37(\mathrm{~s}$, $1 \mathrm{H}) ;{ }^{13} \mathrm{C}-\mathrm{NMR}\left(\mathrm{CDCl}_{3}\right) \delta 21.34,52.13,55.37,110.99,120.23$, $122.83,131.14,139.56,159.51,167.13$.

1-(3-Methoxy-5-methylphenyl)-2-(pyridin-4-yl)ethanone (5): To a solution of the ester 4 (6 g, $33.3 \mathrm{mmol})$ and 4-methylpyridine $(3.4 \mathrm{~g}, 36.6 \mathrm{mmol})$ in THF $(60 \mathrm{~mL})$ was added dropwise lithium bis(trimethylsilyl)amide $1 \mathrm{M} / \mathrm{THF}(50 \mathrm{~mL}, 50.0 \mathrm{mmol})$ at $0^{\circ} \mathrm{C}$ under $\mathrm{N}_{2}$ atmosphere. The mixture was warmed to room temperature and stirred for $18 \mathrm{~h}$. Saturated aqueous ammonium chloride solution $(100 \mathrm{~mL})$ was added to the mixture, followed by extraction with ethylacetate $(200 \mathrm{~mL} \times 2)$. The combined organic layers were washed with saturated $\mathrm{NaCl}$ solution, dried over anhydrous $\mathrm{MgSO}_{4}$ and evaporated under vacuum to yield crude 5 (7.96 g, 99\%) as a brown oil which was used for the next step without further purification. ${ }^{1} \mathrm{H}-\mathrm{NMR}\left(\mathrm{CDCl}_{3}\right) \delta 2.38$ $(\mathrm{s}, 3 \mathrm{H}), 3.82(\mathrm{~s}, 3 \mathrm{H}), 4.29(\mathrm{~s}, 2 \mathrm{H}), 6.65(\mathrm{~s}, 1 \mathrm{H}), 6.71(\mathrm{~s}, 1 \mathrm{H}), 6.80$ $(\mathrm{s}, 1 \mathrm{H}), 7.01(\mathrm{~d}, J=5.8 \mathrm{~Hz}, 2 \mathrm{H}),(\mathrm{s}, 1 \mathrm{H}), 8.48(\mathrm{~d}, J=5.7 \mathrm{~Hz}, 2 \mathrm{H})$; ${ }^{13} \mathrm{C}-\mathrm{NMR}\left(\mathrm{CDCl}_{3}\right) \delta$ 21.39, 44.47, 55.24, 111.61, 115.27, $122.78,124.24,138.07,139.81,147.12,151.92,161.11,197.55$.

4-(3-Methoxy-5-methylphenyl)-5-(pyridin-4-yl)pyrimidin2-amine (6): A mixture of compound 5 (7.96 g, $33.0 \mathrm{mmol}$ ) and $N, N$-dimethylformamide dimethylacetal $(30 \mathrm{~mL}, 255.0 \mathrm{mmol})$ was heated under reflux in an oil bath for $12 \mathrm{~h}$. The excess unreacted $N, N$-dimethylformamide dimethylacetal was removed under vacuum, and the residue was dissolved in absolute ethanol $(100 \mathrm{~mL})$ to form portion $\mathrm{A}$. In portion $\mathrm{B}$, an ethanolic solution of sodium ethoxide was prepared by dissolving sodium metal $(0.84 \mathrm{~g}, 36.3 \mathrm{mmol})$ in absolute ethanol $(50 \mathrm{~mL})$, and then guanidine hydrochloride $(3.47 \mathrm{~g}, 36.3 \mathrm{mmol})$ was added. The mixture was stirred at room temperature for $1 \mathrm{~h}$, then portion $\mathrm{A}$ was added. The temperature was raised to reflux, and the mixture was heated for $8 \mathrm{~h}$. The reaction mixture was left to cool to room temperature, and then cooled in ice water. The crystallized product $\mathbf{6}$ was collected by filtration, washed first with cold ethanol, then with water $(6.0 \mathrm{~g}, 62 \%)$ : $\mathrm{mp} 204-205^{\circ} \mathrm{C}$; IR v/ $\mathrm{cm}^{-1}$ : $3320,3167,1647,1597,1576,1552,1475,1404,1214,1153$, $1060 ;{ }^{1} \mathrm{H}-\mathrm{NMR}\left(\mathrm{CDCl}_{3}\right) \delta 2.25(\mathrm{~s}, 3 \mathrm{H}), 3.62(\mathrm{~s}, 3 \mathrm{H}), 5.49(\mathrm{~s}, 2 \mathrm{H})$, $6.61(\mathrm{~s}, 1 \mathrm{H}), 6.72(\mathrm{~s}, 1 \mathrm{H}), 6.79(\mathrm{~s}, 1 \mathrm{H}), 7.07(\mathrm{dd}, J=1.5,3.2 \mathrm{~Hz}$, $2 \mathrm{H}), 8.33$ (s, 1H), 8.50 (dd, $J=1.4,3.3 \mathrm{~Hz}, 2 \mathrm{H}) ;{ }^{13} \mathrm{C}-\mathrm{NMR}$ $\left(\mathrm{CDCl}_{3}\right) \delta 21.44,55.14,111.65,116.55,121.35,122.47,123.94$, $138.24,139.73,145.32,149.78,159.32,159.38,162.57,165.59$.

4-(3-Methoxy-5-methylphenyl)- $\mathrm{N}, \mathrm{N}$-dimethyl-5-(pyridin4-yl)pyrimidin-2-amine (7): A mixture of the amine 6 (100 mg,
$0.342 \mathrm{mmol}$ ) and sodium hydride (10 mg, $0.41 \mathrm{mmol})$ was stirred in dry DMF $(3.0 \mathrm{~mL})$ at room temperature and under $\mathrm{N}_{2}$ atmosphere for $1 \mathrm{~h}$. To the stirred mixture was added iodomethane (60 mg, $0.41 \mathrm{mmol}$ ) dropwise, and stirring was maintained for more $24 \mathrm{~h}$. The reaction mixture was poured over ice brine $(50$ $\mathrm{mL}$ ), and the resulted precipitate was collected by filtration, washed with cold water and dried. The dried solid was then purified by column chromatography (silica gel, ethyl acetate-hexane $1: 1 \mathrm{v} / \mathrm{v})$ to yield pure $7(20 \mathrm{mg}, 19 \%) ; \mathrm{mp} 94-95^{\circ} \mathrm{C}$; IR v/cm ${ }^{-1}$ : $3438,2926,1583,1550,1408 ;{ }^{1} \mathrm{H}-\mathrm{NMR}\left(\mathrm{CDCl}_{3}\right) \delta 2.25(\mathrm{~s}, 3 \mathrm{H})$, $3.30(\mathrm{~s}, 6 \mathrm{H}), 3.64(\mathrm{~s}, 3 \mathrm{H}), 6.72(\mathrm{~s}, 2 \mathrm{H}), 6.82(\mathrm{~s}, 1 \mathrm{H}), 7.06(\mathrm{~d}, J=$ $5.9 \mathrm{~Hz}, 2 \mathrm{H}), 8.36(\mathrm{~s}, 1 \mathrm{H}), 8.48(\mathrm{~d}, J=5.7 \mathrm{~Hz}, 2 \mathrm{H})$.

$\mathrm{N}$-Benzyl-4-(3-methoxy-5-methylphenyl)-5-(pyridin-4-yl) pyrimidin-2-amine (8): A mixture of the amine $6(100 \mathrm{mg}, 0.34$ $\mathrm{mmol})$ and $\mathrm{K}_{2} \mathrm{CO}_{3}$ in DMF $(3 \mathrm{~mL})$ was stirred at $80{ }^{\circ} \mathrm{C}$ for 30 minutes. Benzyl chloride ( $48 \mathrm{mg}, 0.38 \mathrm{mmol}$ ) in DMF (1 mL) was added to the reaction mixture in 6 portions over a period of $2 \mathrm{~h}$ while heating and stirring were maintained. After complete addition of the reagent, heating and stirring were continued for 2 more hours. The reaction mixure was left to cool, and then poured over ice water $(50 \mathrm{~mL})$. The resulted precipitate was collected by filtration, washed with cold water and dried. Purification of the crude product with column chromatography ( silica gel, ethyl acetate-hexane 1:2 v/v) yielded pure 8 (45 mg, 34\%): $\mathrm{mp} 67-68^{\circ} \mathrm{C}$; IR v/cm ${ }^{-1} 3431,3258,2920,1579,1517,1416$, 1059; ${ }^{1} \mathrm{H}-\mathrm{NMR}\left(\mathrm{CDCl}_{3}\right) \delta 2.23(\mathrm{~s}, 3 \mathrm{H}), 3.60(\mathrm{~s}, 3 \mathrm{H}), 4.68(\mathrm{~d}$, $J=5.7 \mathrm{~Hz}, 2 \mathrm{H}), 6.63(\mathrm{~s}, 1 \mathrm{H}), 6.71(\mathrm{~s}, 1 \mathrm{H}), 6.78(\mathrm{~s}, 1 \mathrm{H}), 7.03(\mathrm{~d}$, $J=5.7 \mathrm{~Hz}, 2 \mathrm{H}), 7.24-7.40(\mathrm{~m}, 6 \mathrm{H}), 8.48(\mathrm{~d}, J=5.8 \mathrm{~Hz}, 2 \mathrm{H})$; ${ }^{13} \mathrm{C}-\mathrm{NMR}\left(\mathrm{CDCl}_{3}\right) \delta 21.45,45.57,55.11,111.76,116.49,120.38$, $122.73,123.92$, 127.27, 127.65, 128.57, 138.58, 139.09, 139.50, $145.63,149.73,159.20,159.25,161.83,165.09$.

General procedure for the synthesis of 9a-d. A mixture of the amine $\mathbf{6}(100 \mathrm{mg}, 0.34 \mathrm{mmol})$, the appropriate arylbromide $(0.41$ $\mathrm{mmol}$ ), dichlorobis(triphenylphosphine)Pd(II) (24 mg, 0.034 mmol), Xantphos (20 mg, $0.034 \mathrm{mmol}$ ) and sodium tert-butoxide $(50 \mathrm{mg}, 0.51 \mathrm{mmol})$ was refluxed in toluene $(5 \mathrm{~mL})$ under nitrogen atmosphere for $12 \mathrm{~h}$. The reaction mixture was left to cool at room temperature, and then cooled in an ice bath. The formed solid was filtered, washed with cold toluene $(10 \mathrm{~mL})$, then with water $(50 \mathrm{~mL})$ to yield the pure target compounds 9a-d.

4-(3-Methoxy-5-methylphenyl)- $N$-phenyl-5-(pyridin-4-yl) pyrimidin-2-amine (9a): Yield (100 mg, 79\%); mp $128-129^{\circ} \mathrm{C}$; IR v/cm ${ }^{-1} 3437,3249,1582,1561,1448 ;{ }^{1} \mathrm{H}-\mathrm{NMR}\left(\mathrm{CDCl}_{3}\right) \delta$ $2.27(\mathrm{~s}, 3 \mathrm{H}), 3.66(\mathrm{~s}, 3 \mathrm{H}), 6.73(\mathrm{~s}, 1 \mathrm{H}), 6.76(\mathrm{~s}, 1 \mathrm{H}), 6.85(\mathrm{~s}, 1 \mathrm{H})$, $7.07-7.13(\mathrm{~m}, 3 \mathrm{H}), 7.38(\mathrm{t}, J=7.9 \mathrm{~Hz}, 2 \mathrm{H}), 7.46(\mathrm{~s}, 1 \mathrm{H}), 7.71(\mathrm{~d}$, $J=7.8 \mathrm{~Hz}, 2 \mathrm{H}), 8.47(\mathrm{~s}, 1 \mathrm{H}), 8.54(\mathrm{~d}, J=6.0 \mathrm{~Hz}, 2 \mathrm{H}) ;{ }^{3} \mathrm{C}-\mathrm{NMR}$ $\left(\mathrm{CDCl}_{3}\right) \delta 21.51,55.17,111.74,116.75,119.42,122.19,122.74$, 122.94, 123.94, 129.03, 138.20, 139.17, 139.70, 145.24, 149.91, $159.09,159.36,159.54,165.12$.

1-(4-(4-(3-Methoxy-5-methylphenyl)-5-(pyridin-4-yl)pyrimidin-2-ylamino)phenyl)ethanone (9b): Yield (106 mg, 76\%); $\mathrm{mp} 129-130^{\circ} \mathrm{C}$; IR v/ $\mathrm{cm}^{-1} 3438,1673,1600,1575,1516,1435$, 1274,$1177 ;{ }^{1} \mathrm{H}-\mathrm{NMR}\left(\mathrm{CDCl}_{3}\right) \delta 2.28(\mathrm{~s}, 3 \mathrm{H}), 2.60(\mathrm{~s}, 3 \mathrm{H}), 3.66$ $(\mathrm{s}, 3 \mathrm{H}), 6.73(\mathrm{~s}, 1 \mathrm{H}), 6.77(\mathrm{~s}, 1 \mathrm{H}), 6.86(\mathrm{~s}, 1 \mathrm{H}), 7.14(\mathrm{~d}, J=5.6$ $\mathrm{Hz}, 2 \mathrm{H}), 7.71(\mathrm{~s}, 1 \mathrm{H}), 7.84(\mathrm{~d}, J=8.7 \mathrm{~Hz}, 2 \mathrm{H}), 7.99(\mathrm{~d}, J=8.7$ $\mathrm{Hz}, 2 \mathrm{H}), 8.52(\mathrm{~s}, 1 \mathrm{H}), 8.57(\mathrm{~d}, J=5.6 \mathrm{~Hz}, 2 \mathrm{H}) ;{ }^{13} \mathrm{C}-\mathrm{NMR}$ $\left(\mathrm{CDCl}_{3}\right) \delta 21.52,26.38,55.19,111.92,116.82,117.95,122.73$, 
$123.24,123.92,128.23,129.04,129.93,131.37,137.91,139.81$, $143.80,144.91,150.03,158.98,159.08,159.44,165.21,196.81$.

N-(3,5-Bis(trifluoromethyl)phenyl)-4-(3-methoxy-5-methylphenyl)-5-(pyridin-4-yl)pyrimidin-2-amine (9c): Yield (128 $\mathrm{mg}, 74 \%) ; \mathrm{mp}>300^{\circ} \mathrm{C}$; IR v/ $\mathrm{cm}^{-1} 3421,3143,1662,1553$, $1445,1200,603 ;{ }^{1} \mathrm{H}-\mathrm{NMR}\left(\mathrm{DMSO}-d_{6}\right) \delta 2.24(\mathrm{~s}, 3 \mathrm{H}), 3.54(\mathrm{~s}$, $3 \mathrm{H}), 6.60(\mathrm{~s}, 1 \mathrm{H}), 6.83(\mathrm{~s}, 1 \mathrm{H}), 6.98(\mathrm{~s}, 1 \mathrm{H}), 7.26(\mathrm{~d}, J=6.0 \mathrm{~Hz}$, 2H), $7.62(\mathrm{~s}, 1 \mathrm{H}), 8.53(\mathrm{~d}, J=6.0 \mathrm{~Hz}, 2 \mathrm{H}), 8.63(\mathrm{~s}, 2 \mathrm{H}), 8.71(\mathrm{~s}$, $1 \mathrm{H}), 10.68(\mathrm{~s}, 1 \mathrm{H}) ;{ }^{13} \mathrm{C}-\mathrm{NMR}$ (DMSO- $\left.d_{6}\right) \delta 21.37,55.28,112.62$, $116.79,118.65,122.10,122.79,123.23,124.55,125.72,130.89$, $131.33,138.39$, 139.70, 142.74, 144.85, 150.14, 159.17, 160.17 .

4-(3-Methoxy-5-methylphenyl)- $\mathrm{N}$-(2,4-dimethylphenyl)5-(pyridin-4-yl)pyrimidin-2-amine (9d): Yield (89 mg, 66\%); mp 175 - $176^{\circ} \mathrm{C}$; IR v/ $\mathrm{cm}^{-1} 3441,2923,1579,1510,1448 ;{ }^{1} \mathrm{H}-$ $\mathrm{NMR}\left(\mathrm{CDCl}_{3}\right) \delta 2.27(\mathrm{~s}, 3 \mathrm{H}), 2.33(\mathrm{~s}, 6 \mathrm{H}), 3.64(\mathrm{~s}, 3 \mathrm{H}), 6.70(\mathrm{~s}$, $1 \mathrm{H}), 6.74(\mathrm{~s}, 1 \mathrm{H}), 6.85(\mathrm{~s}, 1 \mathrm{H}), 7.09(\mathrm{bs}, 5 \mathrm{H}), 7.80(\mathrm{~d}, J=8.2 \mathrm{~Hz}$, $1 \mathrm{H}), 8.41(\mathrm{~s}, 1 \mathrm{H}), 8.53(\mathrm{~d}, J=4.4 \mathrm{~Hz}, 2 \mathrm{H}) ;{ }^{13} \mathrm{C}-\mathrm{NMR}\left(\mathrm{CDCl}_{3}\right)$ $\delta 18.17,20.91,21.49,55.14,111.70,116.67,121.70,122.68$, 123.12, 123.91, 127.20, 130.06, 131.35, 134.24, 134.30, 138.30, 139.67, 145.34, 149.89, 159.27, 159.34, 160.45, 165.27.

General procedure for the synthesis of $10 \mathrm{a}$ and $10 \mathrm{~b}$. To a solution of the amine $6(100 \mathrm{mg}, 0.34 \mathrm{mmol})$ in pyridine $(3 \mathrm{~mL})$ under reflux, was added the appropriate benzoyl chloride $(0.38$ $\mathrm{mmol}$ ) in 8 portions over a period of 2 hours. Heating and stirring were maintained for $2 \mathrm{~h}$ after complete addition of the reagent. Pyridine was removed under vacuum, and the residue was crystallized from ethanol to yield the pure target compounds 10a and $\mathbf{1 0 b}$.

3-(Trifluoromethyl)- $N$-(4-(3-methoxy-5-methylphenyl)-5(pyridin-4-yl)pyrimidin-2-yl)benzamide (10a): Yield (94 mg, $59 \%$ ); mp $208-210^{\circ} \mathrm{C}$; IR v/ $\mathrm{cm}^{-1} 3438,1600,1435,1251$, 1054; ${ }^{1} \mathrm{H}-\mathrm{NMR}\left(\mathrm{CDCl}_{3}\right) \delta 2.27(\mathrm{~s}, 3 \mathrm{H}), 3.62(\mathrm{~s}, 3 \mathrm{H}), 6.65(\mathrm{~s}$, $1 \mathrm{H}), 6.76(\mathrm{~s}, 1 \mathrm{H}), 6.86(\mathrm{~s}, 1 \mathrm{H}), 7.16(\mathrm{~d}, J=5.8 \mathrm{~Hz}, 2 \mathrm{H}), 7.68(\mathrm{t}$, $J=7.7 \mathrm{~Hz}, 1 \mathrm{H}), 7.87(\mathrm{~d}, J=7.6 \mathrm{~Hz}, 1 \mathrm{H}), 8.17(\mathrm{~d}, J=7.7 \mathrm{~Hz}, 1 \mathrm{H})$, $8.23(\mathrm{~s}, 1 \mathrm{H}), 8.60(\mathrm{~d}, J=5.8 \mathrm{~Hz}, 2 \mathrm{H}), 8.72(\mathrm{~s}, 1 \mathrm{H}), 8.98(\mathrm{~s}, 1 \mathrm{H})$; ${ }^{13} \mathrm{C}-\mathrm{NMR}\left(\mathrm{CDCl}_{3}\right) \delta 21.47,55.16,99.42,99.83,111.95,117.16$, $122.72,123.91,124.54,126.70,129.10,129.56,131.03,131.18$, $135.04,136.98,140.01,144.15,150.19,157.16,159.41,159.51$, $163.93,165.49$

3,5-Bis(trifluoromethyl)- $\mathrm{N}$-(4-(3-methoxy-5-methylphenyl)5-(pyridin-4-yl)pyrimidin-2-yl)benzamide (10b): Yield (115 $\mathrm{mg}, 63 \%$ ); $\mathrm{mp} 276-277^{\circ} \mathrm{C}$; ${ }^{1} \mathrm{H}-\mathrm{NMR}$ (DMSO-d $) \delta 2.20(\mathrm{~s}, 3 \mathrm{H})$, $3.55(\mathrm{~s}, 3 \mathrm{H}), 6.63(\mathrm{~s}, 1 \mathrm{H}), 6.81(\mathrm{~s}, 1 \mathrm{H}), 6.85(\mathrm{~s}, 1 \mathrm{H}), 7.30(\mathrm{~d}, J=$ $5.7 \mathrm{~Hz}, 2 \mathrm{H}), 8.38(\mathrm{~s}, 1 \mathrm{H}), 8.56(\mathrm{~d}, J=5.7 \mathrm{~Hz}, 2 \mathrm{H}), 8.63(\mathrm{~s}, 2 \mathrm{H})$, $8.83(\mathrm{~s}, 1 \mathrm{H}), 11.78(\mathrm{~s}, 1 \mathrm{H})$.

General procedure for the synthesis of $11 \mathrm{a}$ and $11 \mathrm{~b}$. A mixture of the amine 6 ( $100 \mathrm{mg}, 0.34 \mathrm{mmol}$ ) and the appropriate aryl isocyanate $(0.51 \mathrm{mmol})$ was heated in an oil bath at $120^{\circ} \mathrm{C}$ while stirring for $1 \mathrm{~h}$. Ethyl acetate $(10 \mathrm{~mL})$ was added, while heating and stirring were maintained for further 5 minutes. The insoluble product was collected by filtration, washed with hot ethylacetate $(10 \mathrm{~mL} \times 2)$ and dried to yield pure 11a and $\mathbf{1 1 b}$.

1-(4-Chloro-3-(trifluoromethyl)phenyl)-3-(4-(3-methoxy-5methylphenyl)-5-(pyridin-4-yl)pyrimidin-2-yl)urea (11a): Yield (123 mg, 70\%); mp $245-246^{\circ} \mathrm{C}$; IR v/cm ${ }^{-1} 3442,2962,1716$, $1584,1548,1419,1303,1135 ;{ }^{1}$ H-NMR (DMSO- $\left.d_{6}\right) \delta 2.24$ (s, $3 \mathrm{H}), 3.56(\mathrm{~s}, 3 \mathrm{H}), 6.68(\mathrm{~s}, 1 \mathrm{H}), 6.88(\mathrm{~s}, 1 \mathrm{H}), 6.94(\mathrm{~s}, 1 \mathrm{H}), 7.27(\mathrm{~d}$, $J=5.9 \mathrm{~Hz}, 2 \mathrm{H}), 7.69(\mathrm{~d}, J=8.8 \mathrm{~Hz}, 1 \mathrm{H}), 7.82(\mathrm{dd}, J=2.3,6.5 \mathrm{~Hz}$,
1H), $7.97(\mathrm{~d}, J=2.3 \mathrm{~Hz}, 1 \mathrm{H}), 8.55(\mathrm{~d}, J=5.9 \mathrm{~Hz}, 2 \mathrm{H}), 8.78(\mathrm{~s}$, 1H), 10.73 (s, 1H), 11.95 (s, 1H).

1-(3,5-Bis(trifluoromethyl)phenyl)-3-(4-(3-methoxy-5-methylphenyl)-5-(pyridin-4-yl)pyrimidin-2-yl)urea (11b): Yield (135 mg, 72\%); mp $246-247^{\circ} \mathrm{C} ;{ }^{1} \mathrm{H}-\mathrm{NMR}$ (DMSO- $\left.d_{6}\right) \delta 2.23$ $(\mathrm{s}, 3 \mathrm{H}), 3.57(\mathrm{~s}, 3 \mathrm{H}), 6.72(\mathrm{~s}, 1 \mathrm{H}), 6.88(\mathrm{~s}, 1 \mathrm{H}), 6.95(\mathrm{~s}, 1 \mathrm{H}), 7.28$ $(\mathrm{d}, J=5.7 \mathrm{~Hz}, 2 \mathrm{H}), 7.76(\mathrm{~s}, 1 \mathrm{H}), 8.18(\mathrm{~s}, 2 \mathrm{H}), 8.56(\mathrm{~d}, J=5.7 \mathrm{~Hz}$, 2H), 8.80 (s, 1H).

General procedure for the synthesis of $12 \mathrm{a}-\mathrm{g}$. To a solution of the starting methoxy compounds $\mathbf{6 - 1 0 a}(0.20 \mathrm{mmol})$ in dichloromethane $(5 \mathrm{~mL})$ was added borontrifluoride-dimethyl sulfide complex $(0.21 \mathrm{~mL}, 2.0 \mathrm{mmol})$ dropwise at room temperature and under $\mathrm{N}_{2}$ atmosphere. The resulting suspension was stirred for $24 \mathrm{~h}$, and then the mixture was concentrated under vacuum. The residue was partitioned between ethylacetate $(100 \mathrm{~mL})$ and brine $(50 \mathrm{~mL})$. The organic layer was separated and dried over anhydrous $\mathrm{MgSO}_{4}$, then evaporated under vacuum. The residue was then purified by column chromatography to yield the pure hydroxyl products.

3-(2-Amino-5-(pyridin-4-yl)pyrimidin-4-yl)-5-methyl-phenol (12a): Column chromatography (silica, ethyl acetate); Yield (30 mg, 55\%); mp $284-285^{\circ} \mathrm{C}$; IR v/cm ${ }^{-1} 3459,3319,3186$, $1627,1579,1467,1300,1214 ;{ }^{1} \mathrm{H}-\mathrm{NMR}$ (DMSO- $\left.d_{6}\right) \delta 2.13$ (s, $3 \mathrm{H}), 6.43(\mathrm{~s}, 1 \mathrm{H}), 6.58(\mathrm{~s}, 2 \mathrm{H}), 7.00(\mathrm{~s}, 2 \mathrm{H}), 7.11(\mathrm{~d}, J=4.8 \mathrm{~Hz}$, $2 \mathrm{H}), 8.31(\mathrm{~s}, 1 \mathrm{H}), 8.50(\mathrm{~d}, J=4.6 \mathrm{~Hz}, 2 \mathrm{H}), 9.37(\mathrm{~s}, 1 \mathrm{H}) ;{ }^{13} \mathrm{C}-\mathrm{NMR}$ (DMSO-d $) \delta 21.44,113.79,117.17,119.51,121.12,124.19$, 138.94, 139.31, 145.65, 149.87, 157.24, 159.89, 163.49, 165.04 .

3-(2-(Benzylamino)-5-(pyridin-4-yl)pyrimidin-4-yl)-5-methylphenol (12b): Column chromatography (silica, ethyl acetatehexane $1: 1 \mathrm{v} / \mathrm{v})$; Yield (35 mg, 47\%); mp 223 - $224^{\circ} \mathrm{C}$; IR v/ $\mathrm{cm}^{-1} 3431,2923,1579,1415 ;{ }^{1} \mathrm{H}-\mathrm{NMR}$ (DMSO- $\left.d_{6}\right) \delta 2.12(\mathrm{~s}$, $3 \mathrm{H}), 4.58(\mathrm{~d}, J=5.0 \mathrm{~Hz}, 2 \mathrm{H}), 6.46(\mathrm{~s}, 1 \mathrm{H}), 6.58(\mathrm{~s}, 2 \mathrm{H}), 7.18-$ $7.34(\mathrm{~m}, 7 \mathrm{H}), 8.13$ (bs, 1H), 8.37 (s, 1H), $8.46(\mathrm{~s}, 2 \mathrm{H}), 9.37$ (s, $1 \mathrm{H})$.

3-Methyl-5-(2-(phenylamino)-5-(pyridin-4-yl)pyrimidin4-yl)phenol (12c): Column chromatography (silica, ethyl acetate-hexane 1:1 v/v); Yield (30 mg, 42\%); mp $222-223^{\circ} \mathrm{C}$; IR $\mathrm{v} / \mathrm{cm}^{-1} 3437,1580,1511,1446 ;{ }^{1} \mathrm{H}-\mathrm{NMR}\left(\mathrm{CD}_{3} \mathrm{OD}\right) \delta 2.19$ (s, $3 \mathrm{H}), 6.67(\mathrm{~s}, 2 \mathrm{H}), 6.70(\mathrm{~s}, 1 \mathrm{H}), 7.02(\mathrm{t}, J=7.3 \mathrm{~Hz}, 1 \mathrm{H}), 7.25-7.34$ $(\mathrm{m}, 4 \mathrm{H}), 7.78(\mathrm{~d}, J=7.9 \mathrm{~Hz}, 2 \mathrm{H}), 8.43(\mathrm{~d}, J=5.9 \mathrm{~Hz}, 2 \mathrm{H}), 8.49$ (s, 1H)

1-(4-(4-(3-Hydroxy-5-methylphenyl)-5-(pyridin-4-yl)pyrimidin-2-ylamino)phenyl)ethanone (12d): Column chromatography (silica, ethyl acetate); Yield (40 mg, 51\%); mp 184 - 185 ${ }^{\circ} \mathrm{C}$; IR v $/ \mathrm{cm}^{-1} 3431,1576,1517,1436,1279,1179 ;{ }^{1} \mathrm{H}-\mathrm{NMR}$ $\left(\mathrm{CD}_{3} \mathrm{OD}\right) \delta 2.17(\mathrm{~s}, 3 \mathrm{H}), 2.55(\mathrm{~s}, 3 \mathrm{H}), 6.66(\mathrm{~s}, 3 \mathrm{H}), 7.24(\mathrm{~d}, J=$ $4.6 \mathrm{~Hz}, 2 \mathrm{H}), 7.94$ (s, 4H), 8.41 (d, $J=4.2 \mathrm{~Hz}, 2 \mathrm{H}), 8.49$ (s, 1H); ${ }^{13} \mathrm{C}-\mathrm{NMR}\left(\mathrm{CD}_{3} \mathrm{OD}\right) \delta 20.01,24.99,113.38,116.99,117.66$, $121.38,122.18,124.39,129.49,130.20,138.34,139.30,145.19$, 146.41, 148.59, 157.09, 158.93, 159.27, 165.11, 198.09.

3-(2-(3,5-Bis(trifluoromethyl)phenylamino)-5-(pyridin-4yl)pyrimidin-4-yl)-5-methylphenol (12e): Column chromatography (silica, ethyl acetate-hexane 1:3 v/v); Yield (39 mg, $40 \%$ ); mp $258-259^{\circ} \mathrm{C}$; IR v/cm ${ }^{-1}: 3437,1565,1441,1377$, 1276, 1179, 1133; ${ }^{1} \mathrm{H}-\mathrm{NMR}$ (DMSO-d $\left.d_{6}\right) 2.29(\mathrm{~s}, 3 \mathrm{H}), 6.46(\mathrm{~s}$, $1 \mathrm{H}), 6.73(\mathrm{~s}, 1 \mathrm{H}), 7.14(\mathrm{~s}, 1 \mathrm{H}), 7.18(\mathrm{~d}, J=5.1 \mathrm{~Hz}, 2 \mathrm{H}), 7.47(\mathrm{~s}$, $1 \mathrm{H}), 8.27(\mathrm{~d}, J=5.1 \mathrm{~Hz}, 2 \mathrm{H}), 8.35(\mathrm{~s}, 2 \mathrm{H}), 8.45(\mathrm{~s}, 1 \mathrm{H}), 8.74(\mathrm{~s}$, 1H), $9.79(\mathrm{~s}, 1 \mathrm{H}) ;{ }^{13} \mathrm{C}-\mathrm{NMR}$ (DMSO-d $) \delta 21.33,114.18,117.89$, 
$118.65,121.15,122.11,123.04,124.39,125.73,130.91,131.34$, $138.47,139.45,142.80,144.76,150.13,157.34,159.11,160.16$, 164.59 .

3-(2-(2,4-Dimethylphenylamino)-5-(pyridin-4-yl)pyrimidin-4-yl)-5-methylphenol (12f): Column chromatography (silica, ethyl acetate-hexane 1:2 v/v); Yield (35 mg, 46\%); mp 113 $115^{\circ} \mathrm{C}$; IR v $/ \mathrm{cm}^{-1} 3652,2922,1713,1578,1510,1452,1408$; ${ }^{1} \mathrm{H}-\mathrm{NMR}\left(\mathrm{CD}_{3} \mathrm{OD}\right) \delta 2.17$ (s, 3H), $2.28(\mathrm{~s}, 3 \mathrm{H}), 2.31$ (s, 3H), 6.59 $(\mathrm{s}, 1 \mathrm{H}), 6.64(\mathrm{~s}, 1 \mathrm{H}), 6.66(\mathrm{~s}, 1 \mathrm{H}), 7.03(\mathrm{~d}, J=8.1 \mathrm{~Hz}, 1 \mathrm{H}), 7.08$ (s, 1H), $7.22(\mathrm{dd}, J=1.6,3.1 \mathrm{~Hz}, 2 \mathrm{H}), 7.48(\mathrm{~d}, J=8.00 \mathrm{~Hz}, 1 \mathrm{H})$, $8.36(\mathrm{~s}, 1 \mathrm{H}), 8.40$ (dd, $J=1.5,3.1 \mathrm{~Hz}, 2 \mathrm{H}) ;{ }^{13} \mathrm{C}-\mathrm{NMR}\left(\mathrm{CD}_{3} \mathrm{OD}\right)$ $\delta 16.91,19.61,19.98,113.24,116.87,120.60,121.19,124.28$, $124.72,126.56,130.80,132.17,134.39,134.63,138.50,139.26$, $146.61,148.52,157.02,158.85,160.78,165.78$.

3-(Trifluoromethyl)- $\mathrm{N}$-(4-(3-hydroxy-5-methylphenyl)-5(pyridin-4-yl)pyrimidin-2-yl)benzamide (12g): Column chromatography ( silica, ethyl acetate-hexane 1:1 v/v); Yield (57 mg, $63 \%$ ); mp $230-231{ }^{\circ} \mathrm{C}$; IR v/ $\mathrm{cm}^{-1} 3438,2923,1616,1562$, 1494, 1460, 1125; ${ }^{1} \mathrm{H}-\mathrm{NMR}$ (DMSO-d $\left.d_{6}\right) 2.19$ (s, 3H), 6.68 $6.82(\mathrm{~m}, 3 \mathrm{H}), 7.52(\mathrm{~s}, 2 \mathrm{H}), 7.90(\mathrm{~s}, 1 \mathrm{H}), 8.15(\mathrm{~s}, 1 \mathrm{H}), 8.55$ - 8.68 $(\mathrm{m}, 4 \mathrm{H}), 9.05(\mathrm{~s}, 1 \mathrm{H}), 9.66(\mathrm{~s}, 1 \mathrm{H})$.

General procedure for the synthesis of $13 \mathrm{a}$ and $13 \mathrm{~b}$. A mixture of the phenolic amine 12a $(50 \mathrm{mg}, 0.18 \mathrm{mmol})$ and the appropriate isocyanate $(0.27 \mathrm{mmol})$ was heated in an oil bath at $120^{\circ} \mathrm{C}$ with stirring for $1 \mathrm{~h}$. The resulted solid was then dissolved in ethylacetate $(2 \mathrm{~mL})$ and purified with column chromatography (silica gel, ethyl acetate) to yield the pure products 13a and $13 \mathrm{~b}$.

1-(4-Chloro-3-(trifluoromethyl)phenyl)-3-(4-(3-hydroxy-5methylphenyl)-5-(pyridin-4-yl)pyrimidin-2-yl)urea (13a): Yield (58 mg, 64\%); mp $272-273^{\circ} \mathrm{C}$; IR v/cm $\mathrm{cm}^{-1} 3437,1703,1583$, $1558,1483,1420,1324,1139,646 ;{ }^{1} \mathrm{H}-\mathrm{NMR}$ (DMSO- $\left.d_{6}\right) \delta 2.18$ $(\mathrm{s}, 3 \mathrm{H}), 6.55(\mathrm{~s}, 1 \mathrm{H}), 6.68(\mathrm{~s}, 1 \mathrm{H}), 6.77(\mathrm{~s}, 1 \mathrm{H}), 7.26(\mathrm{~s}, 2 \mathrm{H}), 7.66$ $(\mathrm{d}, J=8.4 \mathrm{~Hz}, 1 \mathrm{H}), 7.77(\mathrm{~d}, J=7.8 \mathrm{~Hz}, 1 \mathrm{H}), 8.00(\mathrm{~s}, 1 \mathrm{H}), 8.54$ (s, 2H), $8.73(\mathrm{~s}, 1 \mathrm{H}), 9.47(\mathrm{~s}, 1 \mathrm{H}), 10.55(\mathrm{~s}, 1 \mathrm{H}), 11.91(\mathrm{~s}, 1 \mathrm{H})$.

1-(3,5-Bis(trifluoromethyl)phenyl)-3-(4-(3-hydroxy-5-methylphenyl)-5-(pyridin-4-yl)pyrimidin-2-yl)urea (13b): Yield (74 mg, 77\%); mp > $300{ }^{\circ} \mathrm{C} ;{ }^{1} \mathrm{H}-\mathrm{NMR}$ (DMSO-d 6 ) $\delta 2.34$ (s, 3H), 7.13-7.27 (m, 5H), $7.59(\mathrm{~s}, 2 \mathrm{H}), 7.95(\mathrm{~s}, 2 \mathrm{H}), 8.03-8.07(\mathrm{~m}, 2 \mathrm{H})$, $8.66-8.79(\mathrm{~m}, 2 \mathrm{H}), 11.89(\mathrm{~s}, 1 \mathrm{H})$.

Cell-line screening. Cell-line screening was applied at the National Cancer Institute (NCI), Bethesda, Maryland, USA. ${ }^{15}$ applying the following procedure. The human tumor cell lines of the cancer screening panel are grown in RPMI 1640 medium containing $5 \%$ fetal bovine serum and $2 \mathrm{mM} \mathrm{L}$-glutamine. For a typical screening experiment, cells are inoculated into 96 well microtiter plates in $100 \mu \mathrm{L}$ at plating densities ranging from 5,000 to 40,000 cells/well depending on the doubling time of individual cell lines. After cell inoculation, the microtiter plates are incubated at $37{ }^{\circ} \mathrm{C}, 5 \% \mathrm{CO}_{2}, 95 \%$ air and $100 \%$ relative humidity for $24 \mathrm{~h}$ prior to addition of experimental drugs. After $24 \mathrm{~h}$, two plates of each cell line are fixed in situ with TCA, to represent a measurement of the cell population for each cell line at the time of drug addition (Tz). Experimental drugs are solubilized in dimethyl sulfoxide at 400-fold the desired final maximum test concentration and stored frozen prior to use. At the time of drug addition, an aliquot of frozen concentrate is thawed and diluted to twice the desired final maximum test con- centration with complete medium containing $50 \mu \mathrm{g} / \mathrm{mL}$ gentamicin. Additional four, 10 -fold or $1 / 2 \log$ serial dilutions are made to provide a total of five drug concentrations plus control. Aliquots of $100 \mu \mathrm{L}$ of these different drug dilutions are added to the appropriate microtiter wells already containing $100 \mu \mathrm{L}$ of medium, resulting in the required final drug concentrations. Following drug addition, the plates are incubated for an additional $48 \mathrm{~h}$ at $37^{\circ} \mathrm{C}, 5 \% \mathrm{CO}_{2}, 95 \%$ air, and $100 \%$ relative humidity.

For adherent cells, the assay is terminated by the addition of cold TCA. Cells are fixed in situ by the gentle addition of $50 \mu \mathrm{L}$ of cold $50 \%(\mathrm{w} / \mathrm{v})$ TCA (final concentration, 10\% TCA) and incubated for 60 minutes at $4{ }^{\circ} \mathrm{C}$. The supernatant is discarded, and the plates are washed five times with tap water and air dried. Sulforhodamine B (SRB) solution $(100 \mu \mathrm{L})$ at $0.4 \%(\mathrm{w} / \mathrm{v})$ in $1 \%$ acetic acid is added to each well, and plates are incubated for 10 minutes at room temperature. After staining, unbound dye is removed by washing five times with $1 \%$ acetic acid and the plates are air dried. Bound stain is subsequently solubilized with 10 $\mathrm{mM}$ trizma base, and the absorbance is read on an automated plate reader at a wavelength of $515 \mathrm{~nm}$. For suspension cells, the methodology is the same except that the assay is terminated by fixing settled cells at the bottom of the wells by gently adding $50 \mu \mathrm{L}$ of $80 \%$ TCA (final concentration, 16\% TCA). Using the seven absorbance measurements [time zero, (Tz), control growth, $(\mathrm{C})$, and test growth in the presence of drug at the five concentration levels (Ti)], the percentage growth is calculated at each of the drug concentrations levels. Percentage growth inhibition is calculated as: $[(\mathrm{Ti}-\mathrm{Tz}) /(\mathrm{C}-\mathrm{Tz})] \times 100$ for concentrations for which $\mathrm{Ti}>/=\mathrm{Tz}[(\mathrm{Ti}-\mathrm{Tz}) / \mathrm{Tz}] \times 100$ for concentrations for which $\mathrm{Ti}<\mathrm{Tz}$. Three dose response parameters are calculated for each experimental agent. Growth inhibition of $50 \%\left(\mathrm{GI}_{50}\right)$ is calculated from $[(\mathrm{Ti}-\mathrm{Tz}) /(\mathrm{C}-\mathrm{Tz})] \times 100=50$, which is the drug concentration resulting in a $50 \%$ reduction in the net protein increase (as measured by SRB staining) in control cells during the drug incubation. The drug concentration resulting in total growth inhibition (TGI) is calculated from $\mathrm{Ti}=\mathrm{Tz}$. The $\mathrm{LC}_{50}$ (concentration of drug resulting in a $50 \%$ reduction in the measured protein at the end of the drug treatment as compared to that at the beginning) indicating a net loss of cells following treatment is calculated from $[(\mathrm{Ti}-\mathrm{Tz}) / \mathrm{Tz}] \times 100=-50$. Values are calculated for each of these three parameters if the level of activity is reached. However, if the effect is not reached or is exceeded, the value for that parameter is expressed as greater or less than the maximum or minimum concentration tested.

Enzyme screening. Kinase assays were performed at Reaction Biology Corporation using the "HotSpot" assay platform. Kinase Assay Protocol. Reaction Buffer: base Reaction buffer; $20 \mathrm{mM}$ Hepes (pH 7.5), $10 \mathrm{mM} \mathrm{MgCl}, 1 \mathrm{mM}$ EGTA, $0.02 \%$ Brij35, 0.02 mg/mL BSA, 0.1 mM Na$V_{3} V_{4}, 2$ mM DTT, $1 \%$ DMSO. Reaction Procedure: To a freshly prepared buffer solution was added any required cofactor for the enzymatic reaction, followed by the addition of the selected kinase at a concentration of $20 \mu \mathrm{M}$. The contents were mixed gently, and then the compound under test (compound 12e) dissolved in DMSO was added to the reaction mixture in the $10 \mu \mathrm{M}$ concentration. 339-ATP (specific activity $500 \mu \mathrm{Ci} / \mu \mathrm{L}$ ) was added to the mixture in order to initiate the reaction, and the mixture was incubated at room 
temperature for 2 hours. Staurosporine was used as a control compound in a 5-dose $\mathrm{IC}_{50}$ mode with 10 fold serial dilutions starting at $20 \mu \mathrm{M}$, and the reaction was carried out at $10 \mu \mathrm{M}$ ATP concentration.

Acknowledgments. This research was supported by Leading Technology Development Program funded by Small and Medium Business Administration and a grant (K0006028) from the fundamental R\&D program for Core Technology of Materials funded by the Ministry of Knowledge Economy, Republic of Korea. We would like to express our gratitude and thanks to the National Cancer Institute (NCI), Bethesda Maryland, USA for performing the anticancer testing of the new compounds. Our appreciations also for Dr. Sean W. Deacon and Dr. Haiching Ma from Reaction Biology Corporation for carrying out the kinase screening.

\section{References}

1. Powis, G. Trends Pharmacol. Sci. 1991, 12, 188.

2. Capdeville, R.; Buchdunger, E.; Zimmermann, J.; Matter, A. Nat. Rev. Drug Discov. 2002, 1, 493.

3. DeRemer, D. L.; Ustun, C.; Natarajan, K. Clin. Ther. 2008, 30, 1956.

4. Niwa, T.; Asaki, T.; Kimura, S. Anal. Chem. Insights 2007, $2,93$.

5. Fernández, A.; Sanguino, A.; Peng, Z.; Ozturk, E.; Chen, J.; Crespo, A.; Wulf, S.; Shavrin, A.; Qin, C.; Ma, J.; Trent, J.; Lin, Y.; Han, H.-D.; Mangala, L. S.; Bankson, J. A.; Gelovani, J.; Samarel, A.; Bornmann, W.; Sood, A. K.; Lopez-Berestein, G. J. Clin. Invest. 2007, 117, 4044

6. Nuijen, B.; Bouma, M.; Henrar, R. E.; Brauns, U.; Bette, P.; Bult, A.; Beijnen, J. H. Int. J. Pharm. 2000, 194, 261.

7. Steegmaier, M.; Hoffmann, M.; Baum, A.; Lenart, P.; Petronczki, M.; Krssak, M.; Gurtler, U.; Garin-Chesa, P.; Lieb, S.; Quant, J.;
Grauert, M.; Adolf, G. R.; Kraut, N.; Peters, J.-M.; Rettig, W. J. Curr. Biol. 2007, 17, 316.

8. Harris, P. A.; Boloor, A.; Cheung, M.; Kumar, R.; Crosby, R. M.; Davis-Ward, R. G.; Epperly, A. H.; Hinkle, K. W.; Hunter III, R. N.; Johnson, J. H.; Knick, V. B.; Laudeman, C. P.; Luttrell, D. K.; Mook, R. A.; Nolte, R. T.; Rudolph, S. K.; Szewczyk, J. R.; Truesdale, A. T.; Veal, J. M.; Wang, L.; Stafford, J. A. J. Med. Chem. 2008, 51, 4632.

9. Park, B. S.; El-Deeb, I. M.; Yoo, K. H.; Oh, C. H.; Cho, S. J.; Han, D. K.; Lee, H. S.; Lee, J. Y.; Lee, S. H. Bioorg. Med. Chem. Lett. 2009, 19, 4720 .

10. El-Deeb, I. M.; Park, B. S.; Jung, S. J.; Yoo, K. H.; Oh, C. H.; Cho, S. J.; Han, D. K.; Lee, J. Y.; Lee, S. H. Bioorg. Med. Chem. Lett. 2009, 19, 5622.

11. Wipf, P.; Mahler, S. G.; Okumura, K. Org. Lett. 2005, 7, 4483.

12. Turner, F. A.; Gearien, J. E. J. Org. Chem. 1959, 24, 1952.

13. De Frutos, O.; Atienza, C.; Echavarren, A. M. Eur. J. Org. Chem. 2001, $1,163$.

14. El-Deeb, I. M.; Ryu, J. C.; Lee, S. H. Molecules 2008, 13, 818.

15. NCI web site, www.dtp.nci.nih.gov.

16. Reaction Biology Corporation web site, www.reactionbiology. com.

17. Shurin, M. R.; Esche, C.; Lotze, M. T. Cytokine Growth F. R. 1998 , 9, 37.

18. Pratz, K.; Levis, M. Leuk. Lymphoma 2008, 49, 852.

19. Knapper, S.; Burnett, A. K.; Littlewood, T.; Kell, W. J.; Agrawal, S.; Chopra, R.; Clark, R.; Levis, M. J.; Small, D. Blood 2006, 108, 3262.

20. Shankar, D. B.; Li, J.; Tapang, P.; McCall, J. O.; Pease, L. J.; Dai, Y.; Wei, R.-Q.; Albert, D. H.; Bouska, J. J.; Osterling, D. J.; Guo, J.; Marcotte, P. A.; Johnson, E. F.; Soni, N.; Hartandi, K.; Michaelides, M. R.; Davidsen, S. K.; Priceman, S. J.; Chang, J. C.; Rhodes, K.; Shah, N.; Moore, T. B.; Sakamoto, K. M.; Glaser, K. B. Blood 2007, 109, 3400 .

21. Griswold, I. J.; Shen, L. J.; La Rosée, P.; Demehri, S.; Heinrich, M. C.; Braziel, R. M.; McGreevey, L.; Haley, A. D.; Giese, N.; Druker, B. J.; Deininger, M. W. N. Blood 2004, 104, 2912.

22. Bajpai, M. I. Drugs 2009, 12, 174. 